\title{
Pengaruh Pembelajaran Kooperatif Tipe Student Teams Achievement Divisions (STAD) Dan Think-Pair-Share (T-P-S) Terhadap Prestasi Belajar Ditinjau Dari Sikap Ilmiah
}

\author{
Tulus Junanto \\ Pendidikan Kimia, FKIP, Universitas Tanjungpura
}

\begin{abstract}
The purposes of the research is to obtain effect the using of STAD cooperative learning method and T-P-S toward student achievement from scientific attitude. The research used experiment method. The result of the data analysis based on $5 \%$ level signification were found that: 1) $F_{\text {count }}=9,2289$ in effect of learning method toward students achievement, $F_{\text {count }}=8,7450$ in effect of scientific attitude toward students achievement, $F_{\text {count }}=4,5246$ in interaction between method and scientific attitude for cognitive aspect data while $F_{\text {tabel }}=3,97,2$ ) $F_{\text {count }}=5,4759$ in effect of learning method toward students achievement, $F_{\text {count }}=29,9671$ in effect of scientific attitude toward students achievement, $F_{\text {count }}=5,2476$ in interaction between method and scientific attitude for afective aspect data while $F_{\text {tabel }}=3,97$. The conclusion of this research are : 1) student achievement that using cooperative learning type STAD is better than T-P-S type both of cognitive and affective aspect, 2) the students who have high science attitude get student achievement better than the students who have low science attitude both of cognitive and affective aspect, 3) learning method STAD and T-P-S have different effect toward student achievement to student groups who have different science attitude.
\end{abstract}

Keywords : Student Team Achievement Divisions (STAD), Think Pair Share (T-PS), Scientific attitude.

Kemajuan suatu bangsa tidak dapat dipisahkan dari kualitas sumber daya manusia (SDM) dimana hal ini tidak lepas dari mutu pendidikan. Usaha untuk meningkatkan kualitas SDM dilakukan melalui pembelajaran dalam suatu lembaga pendidikan. Pendidikan adalah suatu usaha menumbuh kembangkan potensi sumber daya manusia melalui kegiatan pengajaran. Pendidikan bukanlah sesuatu yang bersifat statis melainkan sesuatu yang bersifat dinamis sehingga selalu menuntut adanya suatu perbaikan yang dilangsungkan terus menerus. Peran pendidikan sangat penting untuk menciptakan kehidupan yang cerdas, damai, terbuka dan demokratis.

Mengajar merupakan bagian dari mendidik. Dalam mengajar dan mendidik dikenal dengan adanya pendekatan dan metode. Pendekatan yang diterapkan dalam pembelajaran bukan saja harus sesuai dengan perkembangan ilmu pengetahuan dan teknologi tapi juga sesuai dengan perkembangan psikologi pebelajar. 
Pembelajaran yang dianut oleh para pembelajar didasarkan atas asumsi bahwa pengetahuan dapat secara utuh dipindahkan dari pikiran pembelajar ke pikiran pebelajar. Para pembelajar memfokuskan diri pada upaya penuangan pengetahuan ke dalam kepala pebelajar tanpa memperhatikan bahwa pebelajar memasuki kelas dengan bekal kemampuan pengetahuan dan motivasi yang tidak sama. Model pembelajaran satu arah dimana pebelajar hanya sebagai obyek dan membatasi kebebasan pebelajar dalam berperan aktif dalam kegiatan belajar mengajar membuat pebelajar menjadi malas dan kurang bersemangat dalam mengikuti pembelajaran.

Suatu realita sehari-hari saat kegiatan belajar mengajar berlangsung nampak beberapa pebelajar atau sebagian pebelajar belum belajar sewaktu pembelajar mengajar di kelas. Beberapa pebelajar belum belajar sampai pada tingkat pemahaman. Pembelajar perlu memberikan dorongan kepada pebelajar untuk menggunakan otoritas atau haknya dalam membangun gagasan. Pembelajar bertanggung jawab untuk menciptakan situasi yang mendorong prakarsa, motivasi dan tanggung jawab pebelajar untuk belajar sepanjang hayat.

Mengajar adalah membimbing kegiatan belajar pebelajar sehingga pebelajar mau belajar. Teaching is the guidance of learning activities, teaching is for purpose of aiding the pupil to learn, demikian menurut William Burton. Aktivitas pebelajar sangat diperlukan dalam kegiatan belajar mengajar sebagai subyek didik. Aktivitas pebelajar ini antara lain aktivitas visual (membaca, melakukan eksperimen), aktivitas oral (bercerita, tanya jawab, diskusi), aktivitas mendengarkan (mendengarkan penjelasan pembelajar, ceramah, pengarahan).

Standar kelulusan di Akademi Analis Kesehatan Nasional Surakarta, dalam memperoleh hasil belajar seorang mahasiswa tidak boleh ada nilai $D$ dan bahkan nilai $E$. Mahasiswa yang mendapat nilai D dianggap tidak lulus dan mengadakan perbaikan nilai atau mengulang untuk mata kuliah tersebut. Nilai akhir mata kuliah Kimia Analitik I terdiri dari nilai rata-rata ulangan harian atau tugas, nilai ujian tengah semester dan nilai ujian semester. Mahasiswa yang tidak lulus diberi kesempatan untuk melakukan remidi atau perbaikan nilai. Hasil nilai mata kuliah Kimia Analitik I semester gasal 2005/ 2006 dan 2006/ 2007 yang diambil berdasarkan nilai tengah semester dan nilai semester saja dari tes kemampuan kognitif dapat dilihat pada tabel 1 sebagai berikut : 
Tabel 1 : Data prosentase nilai Kimia Analitik I.

\begin{tabular}{|c|c|c|c|c|c|c|}
\hline \multirow{2}{*}{ No } & \multirow{2}{*}{ Tahun akademik } & \multicolumn{5}{|c|}{ Prosentase perolehan nilai } \\
\cline { 3 - 7 } & & $\mathrm{A}$ & $\mathrm{B}$ & $\mathrm{C}$ & $\mathrm{D}$ & $\mathrm{E}$ \\
\hline 1. & $2005 / 2006$ & 48,5 & 32 & 12 & 4,5 & 3 \\
\hline 2. & $2006 / 2007$ & 55 & 16 & 19 & 10 & - \\
\hline
\end{tabular}

Dari data di atas dapat dilihat bahwa total prosentase perolehan nilai D kebawah tahun akademik 2005/ 2006 sebanyak 7,5\% atau 5 mahasiswa dari jumlah keseluruhan mahasiswa pada tahun akademik tersebut yaitu 66 mahasiswa. Tahun akademik 2006/ 2007 sebanyak $10 \%$ atau 10 mahasiswa dari jumlah keseluruhan mahasiswa pada tahun akademik tersebut yaitu 70 mahasiswa. Jika kita lihat pada nilai yang tidak lulus, hal ini berarti bahwa terjadi kenaikan prosentase sebesar 2,5\% atau terjadi penurunan kualitas hasil belajar, karena lebih banyak mahasiswa yang tidak lulus dari tahun sebelumnya.

Analisa sementara terjadinya peningkatan jumlah mahasiswa yang tidak lulus ini karena mahasiswa kurang aktif dalam menggali informasi materi kuliah, dominasi pembelajar masih lebih besar dibanding keaktifan mahasiswa dalam pembelajaran, metode ceramah yang digunakan dan tugas yang diberikan belum sepenuhnya mengatasi kesulitan pada mahasiswa. Kemampuan pemahaman pebelajar dalam menerima pelajaran perlu ditingkatkan dan keaktifan pebelajar dalam mengeluarkan pendapatnya perlu dilatih sesuai dengan kemampuan taraf kognitifnya.

Pengetahuan tentang analisa kualitatif diperlukan bukan karena praktek analisanya tetapi juga untuk melatih berpikir teratur dan menarik kesimpulan yang logis. Langkah pertama seorang analisis dalam memastikan suatu bahan yang belum dikenali yaitu dengan memastikan zat-zat apa saja yang terkandung di dalamnya. Langkah selanjutnya adalah menetapkan jumlah komponen yang terkandung di dalam zat tersebut. Salah satu keputusan utama yang diambil oleh seorang analisis adalah memilih prosedur yang paling efektif mengenai suatu analisis tertentu. Ketepatan dan kecermatan dalam melakukan kegiatan analisis sangat diperlukan. Sikap ilmiah seorang analisis sangat diperlukan dalam segala tindakan yang dilakukannya.

Pembelajaran kooperatif merupakan suatu strategi yang melibatkan pembentukan kelompok yang bertujuan pencapaian hasil belajar, penerimaan keberagaman dan keterampilan sosial yang tercipta dalam kerja sama anggota di dalam kelompok tersebut. Pembelajaran kooperatif ini dilaksanakan dengan maksud agar pebelajar dapat lebih membiasakan diri bekerja sama dan belajar berkelompok dalam rangka memecahkan masalah atau mengerjakan tugas.

Berdasarkan uraian di atas, maka usaha untuk perbaikan pendidikan yang dilakukan mengarah kepada pembelajaran yang berpusat pada mahasiswa. Pembelajaran yang 
dirasa cocok untuk mengaktifkan mahasiswa adalah pembelajaran kooperatif tipe STAD dengan pertimbangan hasil penelitian Linda Rundgren (dalam Muslimin Ibrahim,dkk : 2000) menunjukkan bahwa pembelajaran kooperatif memiliki dampak yang positif untuk pebelajar yang mempunyai hasil belajar rendah. Disamping itu pembelajaran kooperatif dapat membantu pebelajar memahami konsep-konsep kimia analisa kualitatif yang sulit serta menumbuhkan kemampuan kerja sama, berpikir kritis, dan mengembangkan sikap sosial pebelajar. Pebelajar bekerja sama dalam situasi semangat pembelajaran kooperatif diantaranya menumbuhkan kerja sama untuk mencapai tujuan bersama dan mengkoordinasikan usahanya untuk menyelesaikan tugas. Sikap sosial pebelajar ditunjukkan dengan saling bantu dalam menyelesaikan masalah dan saling menghormati pendapat orang lain.

Keberhasilan tujuan pembelajaran juga tergantung pada strategi pembelajaran yang digunakan. Pembelajar berinteraksi dengan pebelajar secara langsung dimana pembelajar berperan sebagai fasilitator yang membantu pebelajar dalam mencapai tujuan belajarnya. Salah satu fasilitas yang dapat diusahakan adalah dengan membuat suatu lingkungan pembelajaran yang mendukung pebelajar untuk dapat mengembangkan sikap ilmiah. Dalam mempelajari dan mengembangkan ilmu pengetahuan perlu didukung oleh sikap ilmiah dalam diri setiap pebelajar. Pada intinya sikap ilmiah adalah suatu kecenderungan atau dorongan untuk berperilaku dan mengambil tindakan pemikiran ilmiah sesuai dengan metode ilmiah.

Berdasarkan pemikiran untuk meningkatkan keterlibatan pebelajar dan mengembangkan keberanian pebelajar untuk mengeluarkan pendapat, mengubah pola pikir atau cara belajarnya maka penelitian ini perlu dilakukan. Hal ini sejalan dengan visi dan misi dari Akademi Analis Kesehatan Nasional Surakarta yaitu tentang pengembangan kurikulum yang dinamis serta perbaikan proses belajar mengajar mahasiswa.

Tujuan yang ingin dicapai dalam penelitian ini adalah 1) Untuk mengetahui pengaruh penggunaan pembelajaran kooperatif tipe T-P-S dan STAD terhadap prestasi belajar mahasiswa. 2) Untuk mengetahui apakah terdapat pengaruh sikap ilmiah katagori tinggi dan katagori rendah terhadap prestasi belajar mahasiswa. 3) Untuk mengetahui ada tidaknya interaksi antara penggunaan pembelajaran kooperatif tipe T-P-S dan STAD dengan sikap ilmiah terhadap prestasi belajar mahasiswa.

Berpikir merupakan suatu kegiatan untuk menemukan kegiatan yang benar. Makna benar ini untuk tiap orang berbeda sehingga proses berpikir untuk menghasilkan pengetahuan yang benar berbeda pula. Ciri yang pertama dari suatu penalaran adalah logika yaitu suatu pola pikir yang bersifat luas. Ciri yang kedua bersifat analitik dari proses berpikirnya.

Belajar dapat diartikan sebagai suatu usaha oleh seseorang untuk mendapatkan ilmu yang melalui suatu proses perubahan 
tingkah laku sebagai buah dari pengalaman yang merupakan hasil interaksi dengan lingkungannya dalam usaha memenuhi kebutuhan dan kelangsungan hidupnya. Seseorang dikatakan belajar jika telah mengalami perubahan tingkah laku. Perubahan tingkah laku ini dapat terdiri dari perubahan secara kognitif yang meliputi pengetahuan atau pemahaman, perubahan secara afektif atau perubahan sikap/ nilai, dan perubahan psikomotorik (keterampilan). Pembelajaran merupakan suatu usaha yang dilakukan pembelajar dalam membantu pebelajar mempelajari suatu hal atau nilai yang baru dengan cara interaktif melalui proses yang sistematis.

Belajar tidak berlangsung seketika tetapi berproses pada hal-hal esensial sehingga aktivitas belajar itu akan menimbulkan makna yang berarti (meaningfull). Fungsi motivasi dalam belajar adalah mendorong pebelajar untuk belajar, memberikan arah yang tepat untuk mencapai tujuan dan memilih atau meninggalkan perbuatan mana yang harus dilakukan sehingga pencapaian tujuan dapat direalisasikan. Motivasi merupakan unsur dinamis sebagai penggerak dalam pembelajaran.

Teori belajar konstruktivisme (contructivist theories of learning) menurut Slavin (1997) adalah teori yang berpandangan bahwa pebelajar sendiri yang harus menemukan dan mentransformasikan informasi komplek, mengecek informasi baru, kemudian membandingkan dengan aturan lama dan merevisi aturan itu apabila tidak sesuai lagi. Pendekatan mengajar yang searah dengan teori belajar konstruktivisme salah satunya adalah pembelajaran kooperatif. Konstruktivisme lahir dari gagasan Piaget dan Vygotsky. Keduanya berpandangan bahwa perubahan kognitif hanya terjadi jika konsep yang telah dimiliki sebelumnya diolah melalui proses ketidakseimbangan dalam upaya memahami informasi baru. Keduanya juga menekankan adanya hakekat sosial dari belajar dan menyarankan penggunaan kelompok-kelompok belajar dengan kemampuan anggotanya beragam untuk mengupayakan perubahan konseptual.

Piaget dan Vygotsky keduanya menekankan adanya hakekat sosial atau interaksi sosial di dalam belajar. Keduanya menyarankan penggunaan kelompok-kelompok belajar dengan kemampuan anggota kelompok yang beragam guna mengupayakan perubahan konseptual. Dengan kelompok belajar yang beragam kemampuan anggotanya, pebelajar yang kurang menguasai materi prasyarat diharapkan akan lebih cepat mendapatkan bantuan dari temannya yang lebih mampu. Sementara itu di dalam pembelajaran klasikal kemungkinan pebelajar mendapat bantuan tidak semudah pembelajaraan kooperatif ini.

Pembelajaran kooperatif adalah suatu kegiatan belajar mengajar dengan membuat kelompok belajar dan mengutamakan sikap saling bantu diantara anggota kelompoknya sehingga tercapai kesamaan tujuan dalam mencapai keberhasilan. Pembelajaran koperatif ini berfokus pada pembentukan atau penggunaan kelompok kecil pebelajar dalam memaksimalkan 
kondisi belajar untuk mencapai tujuan belajar.

Aspek penting pembelajaran kooperatif adalah membantu mengembangkan tingkah laku kooperatif dan hubungan yang lebih baik diantara pebelajar, pembelajaran kooperatif secara bersama membantu pebelajar dalam pembelajaran akademis mereka. Peningkatan belajar terjadi tidak bergantung pada usia pebelajar, mata pelajaran, atau aktivitas belajar. Pebelajar lebih memiliki kemungkinan mengunakan tingkat berpikir lebih tinggi selama dan setelah diskusi dalam tugas pemecahan masalah, berpikir kritis dan lainnya. Materi yang dipelajari akan melekat untuk periode waktu yang lebih lama.

STAD dikembangkan oleh Robert Slavin di universitas John Hopkin dan merupakan salah satu pendekatan pembelajaran kooperatif yang paling sederhana serta sebuah bentuk model yang bagus untuk memulainya bagi pembelajar yang baru dalam menggunakan pendekatan kooperatif. Secara umum STAD mempunyai pengaruh secara positif yaitu 1)hubungan antar ras, 2)membantu/menyemangati teman, 3)hubungan antar teman, 4) kerjasama, 5)membentuk sikap di kelas dan sekolah.

Think-Pair-Share digunakan dalam pembelajaran kooperatif dan dikembangkan oleh Frank Lyman dari universitas Maryland. Pendekatan ini memberi penekanan pada penggunaan struktur tertentu yang dirancang untuk mempengaruhi pola interaksi pebelajar. Think-PairShare merupakan suatu strategi yang dirancang untuk menyediakan pebelajar "food for thought" pada sebuah topik yang diberikan yang memungkinkan pebelajar untuk merumuskan ide secara individual dan berbagi ide mereka dengan pebelajar yang lain. Manfaat metode ini bagi pebelajar adalah 1) pebelajar diberi waktu untuk berpikir melalui jawaban mereka sendiri pada sebuah pertanyaan sebelum dijawab oleh pebelajar lain dan didiskusikan, 2) pebelajar mempunyai kesempatan untuk berpikir banyak dengan teman lain tentang pendapat mereka sebelum diminta pendapatnya secara umum di depan kelas, memberi kesempatan pada semua pebelajar untuk membagikan ide mereka paling tidak dengan satu temannya, 4) melibatkan rasa keterlibatan pebelajar pada pembelajaran kelas, 5) sebagai daerah penerimaan pebelajar dalam lingkungan kelas, 6) membantu teman, 7) prestasi akademik, 8) penghargaan diri.

dalam diri manusia $\begin{array}{r}\text { Sikap mang } \\ \text { manakan }\end{array}$ menggerakkan untuk bertindak, menyertai manusia dengan perasaanperasaan tertentu dalam menanggapi obyek dan terbentuk atas dasar pengalaman-pengalaman. Suatu obyek atau stimulus merupakan suatu faktor yang dapat menimbulkan suatu sikap tertentu pada seseorang. Sikap merupakan tenaga pendorong (motif) dari seseorang untuk timbulnya suatu perbuatan atau tindakan. Sikap ilmiah merupakan suatu bentuk sikap tingkah laku yang ditunjukan siswa dalam proses belajar mengajar dengan bercirikan sebgai berikut 1) rasa ingin tahu; 2) jujur; 3) teliti; 4) menghargai pendapat orang lain; 5) mau menerima gagasan baru/ 
terbuka: 6) kritis atau berani menanggapi hal yang kurang jelas atau keliru.

\section{Pada}

prinsipnya

pengungkapan hasil belajar ideal meliputi segenap ranah psikologis yang berubah sebagai akibat dari pengalaman dan proses belajar dari pebelajar. Pengungkapan hal ini sulit dilakukan karena bersifat intangible (tak dapat diraba). Pembelajar hanya mengambil cuplikan perubahan tingkah laku yang dianggap penting dan diharapkan mencerminkan perubahan yang terjadi sebagai hasil belajar, baik yang berdimensi cipta, rasa, maupun karsa.

\section{METODE}

Penelitian ini dilaksanakan di Akademi Analis Kesehatan Nasional Surakarta. Penelitian ini dilaksanakan pada semester satu tahun akademik 2007/2008. Metode penelitian yang digunakan adalah metode penelitian eksperimen dimana dalam metode ini terdapat kelompok eksperimen dan kelompok kontrol. Kedua kelompok ini diasumsikan sama dalam segala segi yang relevan (pokok bahasan, tempat, jumlah jam pelajaran) hanya berbeda dalam pemberian perlakuan mengajar. Kelompok eksperimen diberi perlakuan pembelajaran dengan menggunakan pembelajaran kooperatif tipe STAD dan kelompok kontrol diberi perlakuan pembelajaran dengan mengunakan pembelajaran kooperatif tipe T-P-S.

Sebelum proses belajar mengajar dimulai pada kedua kelompok tersebut diberi tes sikap ilmiah dengan metode angket. Sikap ilmiah dari data yang diperoleh ini dibagi menjadi dua katagori yaitu sikap ilmiah tinggi dan sikap ilmiah rendah. Penilaian aspek afektif menggunakan angket untuk pengumpulan data dengan pilihan jawaban sangat setuju, setuju, netral, tidak setuju dan sangat tidak setuju. Sampel dalam penelitian ini adalah mahasiswa semester satu tahun ajaran 2007/ 2008 peserta mata kuliah Kimia Analitik I di Akademi Analis Kesehatan Nasional Surakarta.

\section{HASIL}

Data yang diperoleh dalam penelitian ini terdiri atas data sikap ilmiah dan data prestasi belajar yang meliputi nilai kemampuan kognitif pada pokok bahasan kimia analisa kualitatif anorganik pendahuluan dan kemampuan afektif. data sikap ilmiah diperoleh dari pemberian angket sikap ilmiah kepada responden. Pembagian katagori sikap ilmiah dikatagorikan dalam dua golongan yaitu sikap ilmiah tinggi dan sikap ilmiah rendah. Pengolongan katagori ini berdasarkan \pm standar deviasi. Deskripsi data sikap ilmiah dapat dilihat pada tabel 2.

Berdasarkan tabel 2 terlihat bahwa untuk kelompok T-P-S nilai tertinggi untuk sikap ilmiah mahasiswa adalah 145, nilai terendahnya 109 sedangkan standar deviasinya adalah 7,74. Untuk kelompok STAD terlihat bahwa nilai tertinggi untuk sikap ilmiah mahasiswa adalah 138, nilai terendahnya 100 sedangkan standar deviasinya adalah 8,47 . Ini artinya bahwa kelompok T-P-S memiliki nilai sikap ilmiah lebih tinggi dari pada kelompok STAD. Sebaran untuk distribusi frekuensi sikap 
ilmiah pada kelompok T-P-S disajikan pada tabel 3.

Tabel 2 Deskripsi Data Sikap Ilmiah Mahasiswa

\begin{tabular}{|c|c|c|c|c|c|}
\hline Kelompok & Jumlah Data & $\begin{array}{c}\text { Nilai } \\
\text { Tertinggi }\end{array}$ & $\begin{array}{c}\text { Nilai } \\
\text { Terendah }\end{array}$ & $\begin{array}{c}\text { Rata- } \\
\text { Rata }\end{array}$ & $\begin{array}{c}\text { Standar } \\
\text { Deviasi }\end{array}$ \\
\hline T-P-S & 36 & 145 & 109 & 123,67 & 7,74 \\
\hline STAD & 36 & 138 & 100 & 119,92 & 8,47 \\
\hline
\end{tabular}

Tabel. 3. Distribusi Frekuensi Sikap Ilmiah Kelompok T-P-S

\begin{tabular}{|c|c|c|c|}
\hline Interval & Frekuensi & Prosentase & $\begin{array}{c}\text { Prosentase } \\
\text { Kumulatif }\end{array}$ \\
\hline $109-115$ & 5 & 13,89 & 13,89 \\
\hline $116-122$ & 11 & 30,56 & 44,44 \\
\hline $123-129$ & 14 & 38,89 & 83,33 \\
\hline $130-136$ & 4 & 11,11 & 94,44 \\
\hline $137-143$ & 1 & 2,78 & 97,22 \\
\hline $144-150$ & 1 & 2,78 & 100,00 \\
\hline & 36 & 100,00 & \\
\hline
\end{tabular}

Pada tabel 3 terihat bahwa frekuensi terbesar yaitu pada interval 123 - 129 berarti mahasiswa yang mendapatkan nilai antara 123 sampai 129 adalah paling banyak.

Distribusi frekuensi sikap ilmiah pada kelompok STAD disajikan pada tabel 4.

Dari tabel 4 terlihat bahwa frekuensi terbesar terletak pada interval 114 120.

Sebaran nilai prestasi belajar pada aspek kognitif hasil penelitian dari masing-masing kelompok disajikan pada tabel 5.
Dari tabel 5 terlihat bahwa nilai tertinggi prestasi mahasiswa pada aspek kognitif untuk kelompok T-P-S adalah 23, nilai terendah 9, rata-rata kelas 18,67 sedangkan standar deviasinya 3,727. Untuk kelompok STAD nilai tertinggi 23, nilai terendah 14 dengan rata-rata kelas 19,72 dan standar deviasinya 2,699 .

Distribusi frekuensi nilai kemampuan kognitif mahasiswa kelompok T-P-S disajikan pada tabel 6. 
Tabel. 4. Distribusi Frekuensi Sikap Ilmiah Kelompok STAD

\begin{tabular}{|c|c|c|c|}
\hline Interval & Frekuensi & Prosentase & Prosentase Kumulatif \\
\hline $100-106$ & 2 & 5,56 & 5,56 \\
\hline $107-113$ & 4 & 11,11 & 16,67 \\
\hline $114-120$ & 16 & 44,44 & 61,11 \\
\hline $121-127$ & 8 & 22,22 & 83,33 \\
\hline $128-134$ & 3 & 8,33 & 91,66 \\
\hline $135-141$ & 3 & 8,33 & 100,00 \\
\hline & 36 & 100.00 & \\
\hline
\end{tabular}

Tabel 5.Deskripsi Data Kemampuan Kognitif Mahasiswa.

\begin{tabular}{|l|c|c|c|c|c|}
\hline Kelompok & $\begin{array}{c}\text { Jumlah } \\
\text { Data }\end{array}$ & $\begin{array}{c}\text { Nilai } \\
\text { Tertinggi }\end{array}$ & $\begin{array}{c}\text { Nilai } \\
\text { Terendah }\end{array}$ & $\begin{array}{c}\text { Rata- } \\
\text { Rata }\end{array}$ & $\begin{array}{c}\text { Standar } \\
\text { Deviasi }\end{array}$ \\
\hline T-P-S & 36 & 23 & 9 & 18,67 & 3,727 \\
\hline STAD & 36 & 23 & 14 & 19,72 & 2,699 \\
\hline
\end{tabular}

Tabel. 6. Distribusi Frekuensi Kemampuan Kognitif Kelompok T-P-S.

\begin{tabular}{|c|c|c|c|}
\hline Interval & Frekuensi & Prosentase & Prosentase Kumulatif \\
\hline $8-10$ & 1 & 2,78 & 2,78 \\
\hline $11-13$ & 3 & 8,33 & 11,11 \\
\hline $14-16$ & 11 & 30,56 & 41,67 \\
\hline $17-19$ & 9 & 25,00 & 66,67 \\
\hline $20-22$ & 8 & 22,22 & 88,89 \\
\hline $23-25$ & 4 & 11,11 & 100,00 \\
\hline & 36 & 100.00 & \\
\hline
\end{tabular}

Tabel. 7. Distribusi Frekuensi Kemampuan Kognitif Kelompok STAD

\begin{tabular}{|c|c|c|c|}
\hline Interval & Frekuensi & Prosentase & Prosentase Kumulatif \\
\hline $13-14$ & 1 & 2,78 & 2,78 \\
\hline $15-16$ & 3 & 8,33 & 11,11 \\
\hline $17-18$ & 9 & 25,00 & 36,11 \\
\hline $19-20$ & 8 & 22,22 & 58,33 \\
\hline $21-22$ & 8 & 22,22 & 80,56 \\
\hline $23-24$ & 7 & 19,44 & 100,00 \\
\hline & 36 & 100.00 & \\
\hline
\end{tabular}


Dari tabel 6 terlihat bahwa frekuensi mutlak terbanyak terletak pada interval nilai 14 - 16. Ini berarti bahwa jumlah mahasiswa mendapatkan nilai antara 14 sampai 16 adalah paling banyak yaitu 30,56 $\%$.

Distribusi frekuensi nilai prestasi mahasiswa pada aspek kognitif kelompok STAD disajikan pada 7 .
Dari table 7 terlihat bahwa frekuensi terbanyak adalah 9 mahasiswa yaitu pada interval nilai 17 sampai 18.

Sebaran nilai prestasi belajar pada aspek afektif hasil penelitian dari masing-masing kelompok baik kelompok T-P-S maupun kelompok STAD disajikan pada tabel 8 berikut

Tabel 8. Deskripsi Data Kemampuan Afektif Mahasiswa

\begin{tabular}{|c|c|c|c|c|c|}
\hline Kelompok & $\begin{array}{c}\text { Jumlah } \\
\text { Data }\end{array}$ & $\begin{array}{c}\text { Nilai } \\
\text { Tertinggi }\end{array}$ & $\begin{array}{c}\text { Nilai } \\
\text { Terendah }\end{array}$ & $\begin{array}{c}\text { Rata- } \\
\text { Rata }\end{array}$ & $\begin{array}{c}\text { Standar } \\
\text { Deviasi }\end{array}$ \\
\hline T-P-S & 36 & 122 & 94 & 105,31 & 7,28 \\
\hline STAD & 36 & 122 & 94 & 108,36 & 6,18 \\
\hline
\end{tabular}

Tabel 9. Distribusi Frekuensi Kemampuan Afektif Kelompok T-P-S

\begin{tabular}{|c|c|c|c|}
\hline Interval & Frekuensi & Prosentase & Prosentase Kumulatif \\
\hline $94-98$ & 6 & 16,67 & 16,67 \\
\hline $99-103$ & 12 & 33,33 & 50,00 \\
\hline $104-108$ & 7 & 19,44 & 69,44 \\
\hline $109-113$ & 6 & 16,67 & 86,11 \\
\hline $114-118$ & 2 & 5,56 & 91,67 \\
\hline $119-123$ & 3 & 8,33 & 100,00 \\
\hline & 36 & 100,00 & \\
\hline
\end{tabular}

Dari tabel 8 terlihat bahwa nilai tertinggi kelompok T-P-S adalah 122, nilai teredahnya 94 dan standar deviasinya 7,24. Untuk kelompok STAD nilai tertingginya 122, nilai terendah 94 dengan standar deviasi 6,18 .

Distribusi frekuensi nilai prestasi belajar mahasiswa pada aspek afektif kelompok T-P-S disajikan pada tabel 9.

Dari tabel 9 dapat dilihat bahwa jumlah frekuensi mutlak mahasiswa yang mendapatkan nilai pada interval 99 - 103 adalah yang terbesar.

Distribusi frekuensi nilai prestasi belajar pada aspek afektif mahasiswa kelompok STAD disajikan pada tabel 10 .

Dari tabel 10 dapat dilihat bahwa frekuensi terbesar adalah pada interval nilai 109 - 113. Ini berarti bahwa mahasiswa yang mendapatkan nilai di atas rata-rata paling banyak yaitu pada interval $109-113$. Data-data yang diperoleh dari hasil penelitian yang berupa skor nilai kemampuan kognitif dan afektif 
mahasiswa. Data yang diperoleh dianalisa dengan menggunakan Analisis Variansi Dua Jalan Sel Tak
Sama dan dilanjutkan dengan uji lanjut.

Tabel 10. Distribusi Frekuensi Kemampuan Afektif kelompok STAD

\begin{tabular}{|c|c|c|c|}
\hline Interval & Frekuensi & Prosentase & Prosentase Kumulatif \\
\hline $94-98$ & 2 & 5,56 & 5,56 \\
\hline $99-103$ & 7 & 19,44 & 25,00 \\
\hline $104-108$ & 8 & 22,22 & 47,22 \\
\hline $109-113$ & 11 & 30,56 & 77,78 \\
\hline $114-118$ & 7 & 19,44 & 97,22 \\
\hline $119-123$ & 1 & 2,78 & 100,00 \\
\hline & 61 & 100.00 & \\
\hline
\end{tabular}

\section{PEMBAHASAN}

1. Hipotesis Pertama

Harga $F_{B}=9,2289$ lebih

besar dari $\mathrm{F}_{\text {tabel }}=3,97$ sehingga hipotesis nol di tolak dan hipotesis alternatif diterima, maka terdapat perbedaan pengaruh penggunaan metode pembelajaran kooperatif tipe T-P-S dengan tipe STAD terhadap kemampuan kognitif pada pembelajaran Kimia Analitik I pokok bahasan analisa kualitatif pendahuluan. Melihat rataan prestasi belajar mahasiswa yang mendapat pembelajaran kooperatif tipe STAD mempunyai prestasi belajar pada aspek kognitif lebih baik dibandingkan dengan yang mendapat pembelajaran kooperatif tipe T-P-S. Data yang diperoleh dari uji lanjut anava yaitu $\mathrm{F}_{\mathrm{B}}=8,8700>\mathrm{F}_{0.05 ; 1: 68}=$ 3.97 maka Ho ditolak. Hal menunjukkan bahwa terdapat perbedaan rerata yang signifikan antara $\mathrm{B}_{1}$ (metode pembelajaran kooperatif tipe T-P-S) dan $\mathrm{B}_{2}$ (metode pembelajaran kooperatif tipe STAD).

Untuk kemampuan afektif menunjukkan bahwa harga $F_{B}=$
5,4759 lebih besar dari $\mathrm{F}_{\text {tabel }}=3,97$ sehingga hipotesis nol di tolak dan hipotesis alternatif diterima, maka terdapat perbedaan pengaruh penggunaan metode pembelajaran kooperatif tipe T-P-S dengan tipe STAD terhadap kemampuan afektif pada pokok bahasan analisa kualitatif pendahuluan. Melihat rataan prestasi belajar mahasiswa yang mendapat pembelajaran kooperatif tipe STAD mempunyai prestasi belajar pada aspek afektif lebih baik dibandingkan dengan yang mendapat pembelajaran kooperatf tipe T-P-S. Data yang diperoleh dari uji lanjut anava yaitu $\mathrm{F}_{\mathrm{B}}=30,3952>\mathrm{F}_{0.05 ; 1: 68}$ $=3,97$ maka Ho ditolak. Hal ini menunjukkan bahwa terdapat perbedaan rerata yang signifikan antara $\mathrm{B}_{1}$ (metode pembelajaran kooperatif tipe T-P-S) dan $\mathrm{B}_{2}$ (metode pembelajaran kooperatif tipe STAD).

Prestasi belajar kemampuan kognitif yang diberi perlakuan dengan metode pembelajaran kooperatif tipe STAD lebih baik dibandingkan dengan metode pembelajaran kooperatif tipe T-P-S 
hal ini disebabkan karena dengan menggunakan metode pembelajaran kooperatif tipe STAD mahasiswa membentuk kelompok yang terdiri dari 4-5 orang dan belajar bersama untuk memecahkan sesuatu masalah dengan cara bekerja sama dengan anggota kelompoknya.

Pembelajaran kooperatif tipe STAD memberi kesempatan kepada mahasiswa selain bekerjasama dalam memecahkan suatu masalah dengan melakukan diskusi, mahasiswa juga mendapat bimbingan dan arahan dari dosen. Pembelajaran kooperatif tipe T-P-S mahasiswa lebih banyak berpikir sendiri dan bekerjasama dengan pasangannya. Kesempatan mahasiswa untuk mendapatkan informasi atau bantuan dari mahasiswa lain dalam memahami suatu permasalahan lebih sedikit dibandingkan dengan pembelajaran kooperatif tipe STAD.

Pembelajaran kooperatif ini mempunyai dampak yang positif untuk pebelajar yang mempunyai hasil belajar rendah. STAD merupakan salah satu pendekatan pembelajaran kooperatif yang paling sederhana sehingga merupakan model yang bagus bagi pembelajar untuk memulai menggunakan metode pembelajaran kooperatif guna meningkatkan prestasi belajar mahasiswa.

\section{Hipotesis kedua}

Harga $\quad F_{A}=8,7450$ lebih besar dari $F_{\text {tabel }}=3,97$ sehingga hipotesis nol ditolak. Hal ini berarti bahwa terdapat perbedaan pengaruh antara sikap ilmiah mahasiswa kategori tinggi dengan kategori rendah terhadap kemampuan kognitif mahasiswa pembelajaran Kimia Analitik I pokok bahasan analisa kualitatif pendahuluan. Melihat rataan prestasi belajar, mahasiswa yang mempunyai sikap ilmiah tinggi memiliki prestasi belajar pada aspek kognitif lebih baik dibandingkan dengan mahasiswa yang mempunyai sikap ilmiah rendah. Data yang diperoleh dari uji lanjut anava yaitu $\mathrm{F}_{\mathrm{A}}=5,5155>\mathrm{F}_{0.05 ; 1: 68}=3.97$ maka Ho ditolak. Hal menunjukkan bahwa terdapat perbedaan rerata yang signifikan antara $\mathrm{A}_{1}$ (metode pembelajaran kooperatif tipe T-P-S) dan $\mathrm{A}_{2}$ (metode pembelajaran kooperatif tipe STAD).

Untuk kemampuan afektif menunjukkan bahwa harga $\mathrm{F}_{\mathrm{A}}=$ 29,9671 lebih besar dari $F_{\text {tabel }}=3,97$ sehingga hipotesis nol di tolak dan hipotesis alternatif diterima, maka terdapat perbedaan pengaruh sikap ilmiah mahasiswa katagori tinggi dan rendah terhadap kemampuan afektif pada pokok bahasan analisa kualitatif pendahuluan. Melihat rataan prestasi belajar mahasiswa yang mempunyai sikap ilmiah tinggi memiliki prestasi belajar pada aspek afektif lebih baik dibandingkan dengan mahasiswa yang memiliki sikap ilmiah rendah. Data yang diperoleh dari uji lanjut anava yaitu $\mathrm{F}_{\mathrm{B}}=30,3952>\mathrm{F}_{0.05 ; 1: 68}$ $=3,97$ maka Ho ditolak. Hal ini menunjukkan bahwa terdapat perbedaan rerata yang signifikan antara $\mathrm{B}_{1}$ (sikap ilmiah tinggi) dan $\mathrm{B}_{2}$ (sikap ilmiah rendah).

Hal ini membuktikan bahwa mahasiswa yang mempunyai sikap ilmiah tinggi akan memberikan pengaruh yang lebih besar dibanding dengan siswa yang mempunyai sikap ilmiah rendah. Sikap seorang mahasiswa menentukan bagaimana ia bereaksi terhadap situasi serta menentukan apa yang dicari dalam 
kehidupannya. Sikap selalu berkenaan dengan suatu obyek dan sikap terhadap obyek itu disertai perasaan positif atau negatif. Mahasiswa yang memiliki sikap ilmiah positif seperti memiliki rasa ingin tahu yang besar dalam menerima ilmu yang baru, bertanggungjawab dalam kelompoknya, teliti dalam mengerjakan tugas. Mahasiswa yang memiliki sikap ilmiah negatif seperti rasa ingin tahunya kurang hal ini terlihat kurang seriusnya mahasiswa pada saat mengerjakan tugas dimana masih ditemukannya mahasiswa yang sedang ngobrol dengan anggota kelompoknya, tidak teliti dalam mengerjakan tugas.

Mahasiswa yang mempunyai sikap ilmiah tinggi lebih mudah memahami dalam menerima penjelasan dibanding dengan mahasiswa yang memiliki sikap ilmiah rendah. Selain itu sikap ilmiah tinggi akan mendukung untuk mereaksi atau merespon suatu tindakan yang baru.

3. Hipotesis Ketiga.

Berdasarkan hasil analisa variansi dua jalan dengan sel tak sama pada aspek kognitif diperoleh harga $\mathrm{F}_{\mathrm{AB}}=4,5246$ lebih besar $\mathrm{F}_{\text {tabel }}$ $=3,97$ sehingga hipotesis nol ditolak. Hal ini berarti bahwa ada interaksi antara metode pembelajaran kooperatif tipe T-P-S dan STAD dengan sikap ilmiah terhadap kemampuan kognitif. Hal ini berarti bahwa jika dilihat pada masingmasing sikap ilmiah mahasiswa (tinggi dan rendah), mahasiswa yang mendapat pembelajaran kooperatif tipe STAD dengan mempunyai prestasi belajar pada aspek kognitif lebih tinggi dibandingkan dengan mahasiswa yang mendapatkan pembelajaran kooperatif tipe T-P-S.

Untuk prestasi belajar dari aspek afektif berdasarkan hasil analisis variansi dua jalan dengan sel tak sama diperoleh harga $\mathrm{F}_{\mathrm{AB}}=$ 5,2476 lebih besar $F_{\text {tabel }}=3,97$ sehingga hipotesis nol ditolak. Hal ini berarti bahwa ada interaksi antara metode pembelajaran kooperatif tipe T-P-S dan STAD dengan sikap ilmiah terhadap prestasi belajar ada aspek afektif. Hal ini berarti bahwa jika dilihat pada masing-masing sikap ilmiah mahasiswa (tinggi dan rendah), mahasiswa yang mendapat pembelajaran kooperatif tipe STAD mempunyai prestasi belajar pada aspek afektif lebih tinggi dibandingkan dengan mahasiswa yang mendapatkan pembelajaran kooperatif tipe T-P-S.

Prestasi belajar aspek kognitif pada mahasiswa yang mempunyai sikap ilmiah tinggi dengan pembelajaran tipe T-P-S reratanya 15,778 dan tipe STAD reratanya 19,333. Hal ini menunjukkan bahwa perlakuan pembelajaran kooperatif tipe STAD lebih baik dibanding tipe T-P-S pada mahasiswa yang mempunyai sikap ilmiah tinggi. Mahasiswa yang mempunyai sikap ilmiah rendah dengan pembelajaran tipe T-P-S reratanya 19,28 dan tipe STAD reratanya 19,90 . Hal ini menunjukkan bahwa perlakuan pembelajaran kooperatif tipe STAD lebih baik dibanding tipe T-P-S pada mahasiswa yang mempunyai sikap ilmiah rendah.

Prestasi belajar aspek afektif pada mahasiswa yang mempunyai sikap ilmiah tinggi dengan pembelajaran tipe T-P-S reratanya 110,667 dan tipe STAD reratanya 
110,733. Hal ini menunjukkan bahwa perlakuan pembelajaran kooperatif tipe STAD lebih baik dibanding tipe T-P-S pada mahasiswa yang mempunyai sikap ilmiah tinggi. Mahasiswa yang mempunyai sikap ilmiah rendah dengan pembelajaran tipe T-P-S reratanya 100,17 dan tipe STAD reratanya 106,43. Hal ini menunjukkan bahwa perlakuan pembelajaran kooperatif tipe STAD lebih baik dibanding tipe T-P-S pada mahasiswa yang mempunyai sikap ilmiah rendah.

\section{SIMPULAN}

Berdasarkan data yang dikumpulkan dari hasil analisis data yang telah dikemukakan dapat disimpulkan sebagai berikut :

1.Terdapat perbedaan yang signifikan pada prestasi belajar Kimia Analitik I pada pokok bahasan analisa kualitatif pendahuluan baik pada aspek kognitif maupun afektif antara mahasiswa yang diberi pembelajaran dengan penggunaan metode pembelajaran kooperatif tipe T-P-S dengan STAD. Mahasiswa yang mendapat pembelajaran dengan metode pembelajaran kooperatif tipe STAD memperoleh prestasi belajar pada aspek kognitif dan afektif lebih tinggi dibanding mahasiswa yang mendapat pembelajaran dengan metode pembelajaran kooperatif tipe T-P-S.

2.Terdapat perbedaan yang signifikan pada prestasi belajar Kimia Analitik I pada pokok bahasan analisa kualitatif pendahuluan baik aspek kognitif maupun aspek afektif antara mahasiswa yang mempunyai sikap ilmiah tinggi dengan mahasiswa yang mempunyai sikap ilmiah rendah. Mahasiswa yang memiliki sikap ilmiah tinggi mendapatkan prestasi belajar yang lebih tinggi dibanding dengan mahasiswa yang memiliki sikap ilmiah rendah.

3.Ada interaksi antara metode pembelajaran kooperatif tipe T-P-S dan STAD dengan sikap ilmiah terhadap prestasi belajar mahasiswa pada aspek kognitif dan afektif pada pokok bahasan analisa kualitatif pendahuluan. Metode pembelajaran kooperatif tipe STAD dan T-P-S memberi pengaruh yang berbeda terhadap prestasi belajar pada kelompok-kelompok mahasiswa yang memepunyai sikap ilmiah yang berbeda.

\section{SARAN}

Berdasarkan kesimpulan dan implikasi dari penelitian maka penulis mengajukan saran-saran sebagai berikut a) Mengingat adanya pengaruh penggunaan antara pembelajaran kooperatif tipe STAD dan T-P-S maka dalam pembelajaran hendaknya dosen dapat mengajar dengan menggunakan model pembelajaran kooperatif yang disesuaikan dengan materi kuliahnya. b) Pembelajaran kooperatif tipe STAD dan T-P-S agar pelaksanaannya berjalan dengan efektif dan efisien perlu diperhatikan beberapa hal yaitu materi, media, dan interaksi antara dosen dengan mahasiswa serta interaksi antar mahasiswa. c) Proses pembelajaran perlu dirancang untuk dapat mengembangkan sikap ilmiah mahasiswa, sehingga mahasiswa yang dapat belajar lebih optimal.

Sikap ilmiah ini dapat dikembangkan dengan berbagai cara 
diantaranya a) Mendorong rasa ingin tahu mahasiswa terhadap ilmu pengetahuan dengan cara melibatkan secara aktif dalam mencari jawaban pertanyaan atau masalah sehingga menjadi pendorong kegiatan ilmiah. Mahasiswa haus akan pengetahan sehingga terus belajar, ada dorongan kuat untuk mengetahui sesuatu. b) Mengajarkan sikap rendah hati kepada mahasiswa dengan memberi pengertian bahwa pengetahuan yang dimiliki manusia sangat terbatas dibanding ilmu pengetahuan yang sangat luas. c) Mahasiswa dilatih agar mempunyai pemikiran alternatif dan menilai pemikiran itu secara obyektif sehingga dapat menerima pendapat orang lain dan gagasan yang baru. d) Menanamkan kejujuran pada mahasiswa. Seorang yang ilmiah dan obyektif berusaha mengambil sikap terbuka dan menampilkan data sekalipun data itu bertentangan dengan harapannya, mendasarkan keputusannya berdasarkan bukti-bukti dan tidak membesar-besarkannya.

\section{DAFTAR PUSTAKA}

Anita Lie. 2002. Cooperative Learning (Mempraktikkan Cooperative Learning di Ruang-ruang Kelas). Jakarta : Grasindo.

Arends, Richard I. 2001. Learning To Teach, $5^{\text {th }}$ edition. Central Connecticut State University, USA : Mc.Graw Hill.

Arief Sidharta. 2004. Macam-Macam Pendekatan Dan Metode Pembelajaran, Bandung : Departemen Pendidikan Nasional.
Armstrong, Scott, Palmer, Jesse. 1998. Student Teams

Achievement Divisions (STAD) in a twelfth grade classroom: Effect on student achievement and attitude, Journal of Social Studies Research, [26 Mei 2007].

Bimo Walgito.1980.Psikologi Sosial

(Suatu Pengantar). Yogyakarta : UGM.

Budiyono.2004. Statistika Untuk Penelitian. Surakarta : UNS Press.

Departemen Pendidikan

Nasional.2003. Pelayanan

Profesional kurikulum 2004

Kegiatan Belajar Mengajar

Yang Efektif. Jakarta :

Departemen Pendidikan

Nasional.

Gino, Suwarni, Suripto Hs, Maryanto, Sutijan.1996.

Belajar Dan Pembelajaran I,

Surakarta : Departemen

Pendidikan Dan Kebudayaan

Republik Indonesia Universitas Sebelas Maret.

Harjadi, W.1990. Ilmu Kimia Analitik Dasar. Jakarta : PT. Gramedia.

Jacobs,George.M., Gan Siowek Lee, Jessica Ball.1996.Learning

Cooperative Learning Via

Cooperative Learning : A

Source Of Lesson Plans For

Teacher Education On

Cooperative Learning,

Singapore : SEAMEO

Regional Language Centre

Singapore.

Jacobsen, David., Paul Eggen, Donald Kauchac. 1989. Method For Teaching, A Skill Aproach, 3rd edition, OHIO : Merril Publishing Company. 
Jujun S Suriasumantri.2003.Filsafat Ilmu Sebuah Pengantar Populer.Jakarta : Pustaka Sinar Harapan.

Kuswadi.2001.Pembelajaran Siswa MTs. Surakarta : FKIP UNS.

Manning,M.Lee.,Robert Lucking.1991.The What, Why, And How Of Cooperative Learning, Washington DC : published by Heldref Publication.

Muhibin Syah.1995. Psikologi Pendidikan. Bandung : PT. Remaja Rosdakarya.

Muslimin Ibrahim, Fida Rachmadiarti, Mohamad Nur, Ismono. 2000. Pembelajaran Kooperatif. Surabaya : University Press.

Ratna Wilis Dahar. 1989. TeoriTeori Belajar. Jakarta : Erlangga.

Slavin, Robert E. 1997.Educational Psycology Theory And Practice. Neecham Heights: A Viocom Company.

Slavin,Robert E.1995. Cooperative Learning, 2nd edition. Massachusetts : A Simon and Schuster Company.

Sri Wardani.2000.Kontruktivisme Teori Dan Implikasinya Dalam Kegiatan Belajar Mengajar Matematika. Jakarta Departemen Pendidikan Nasional.

Suharsimi Arikunto.2005. Manajemen Penelitian, Edisi Revisi, Cetakan ke-7. Jakarta : PT Rineka Cipta.

Sukarjo.2002.Kecenderungan Pembelajaran IPA di SMU, (diberikan sebagai kuliah tambahan/seminar pada program studi Pendidikan
Sains, Program Pascasarjana UNS, tanggal 6 Juni 2002. Solo : UNS.

Syaiful Sagala.2005. Konsep Dan Makna Pembelajaran. Bandung : Alfabeta. 